OmniAkuatika, 11 (2): 15-19, 2015
ISSN: 1858-3873 print / 2476-9347 online
Research Article

\title{
KEPADATAN DAN LAJU PERTUMBUHAN SPESIFIK Nannochloropsis sp. PADA KULTIVASI HETEROTROPIK MENGGUNAKAN MEDIA HIDROLISAT SINGKONG
}

\author{
Mujizat Kawaroe $^{1,2}$, Tri Prartono ${ }^{1}$ dan Ganjar Saefurahman ${ }^{2}$ \\ ${ }^{1}$ Departemen IImu dan Teknologi Kelautan, Institut Pertanian Bogor \\ ${ }^{2}$ Surfactant and Bioenergy Research Center, Institut Pertanian Bogor \\ *Coresponding author: mujizat@ipb.ac.id; mujizatk@gmail.com, trip@ipb.ac.id
}

\begin{abstract}
Growth of Nannochloropsis sp. was observed in laboratory cultivation condition with enrichment of cassava hydrolysate into culture medium as follow : $25 \mathrm{ml}$ microalgae strain, $75 \mathrm{ml}$ seawater, without cassava hydrolysate (A); $25 \mathrm{ml}$ microalgae strain, $25 \mathrm{ml}$ cassava hydrolysate, $50 \mathrm{ml}$ seawater $(B), 25 \mathrm{ml}$ microalgae strain, $50 \mathrm{ml}$ cassava hydrolysate, $25 \mathrm{ml}$ seawater $(C)$. Cultivation condition was fixed as follow temperature $29^{\circ} \mathrm{C}$, seawater $\mathrm{pH} 8$, and salinity $30 \%$. Microalgae cultivation was performed at microalgae laboratory of Surfactant and Bioenergy Research Center using $100 \mathrm{ml}$ Erlenmeyer covered by black plastic to prevent the influence of light. The specific growth rate of Nannochloropsis sp. was observed in 7 days for different cultivation medium composition. The highest density of microalgae was in the $4^{\text {th }}$ days with $50 \mathrm{ml}$ cassava hydrolysate's feeding (C treatment) about $172.661 \mathrm{cell} / \mathrm{mL}$. The highest specific growth rate for Nannochloropsis sp. cultivation was observed in the $6^{\text {th }}$ days without cassava hydrolysate's feeding. Result of statistical analysis showed that different cassava hydrolysate's feeding treatments $(\mathrm{ml})$ in heterotrophically microalgae cultivation influenced the density of microalgae $($ cell $/ \mathrm{mL})$ but not influenced the specific growth rate of microalgae (per day).
\end{abstract}

Keywords: Cassava hydrolysate, Density, Heterotrophic cultivation, Spesific growth rate, Nannochloropsis $s p$.

\section{PENDAHULUAN}

Nannochloropsis sp. lebih dikenal dengan nama Chlorella laut, umumnya dikultivasi untuk pakan Brachionus spp. (Rotifer). Kandungan asam lemak esensial EPA dan DHA yang tinggi membuat organisme ini sangat baik digunakan sebagai pakan hidup rotifer (Lavens, P. dan P. Sorgeloos, 1996). Selain sebagai pakan perikanan, spesies mikroalga ini juga memiliki potensi sebagai sumber bahan bakar nabati dengan kandungan lipid 31$68 \%$ (Chisti, 2007). Hasil penelitian Pusat Penelitian Surfaktan dan Bioenergi IPB (Kawaroe et al, 2008) menunjukkan bahwa Nannochloropsis sp. memiliki kandungan minyak tertinggi (16\%) jika dibandingkan dengan jenis lain, yaitu Chlorella (14\%) dan Scenedesmus (3\%) tanpa penambahan $\mathrm{CO}_{2}$, enzim maupun rekayasa genetik lain.

Sebagian besar spesies mikroalga termasuk ke dalam golongan alga fotoautrotof yang memperoleh energi dari sinar dan karbon dioksida menjadi ikatan atom karbon. Beberapa bagian spesies alga bersifat heterotrof yang tidak memerlukan sinar dan memperoleh karbon dari komponen organik seperti gula dan asam organik.
Beberapa bagian lagi spesies alga termasuk kelompok miksotropik yang dapat melakukan reproduksi sel dalam kondisi pencahayaan sinar maupun tanpa sinar (kondisi gelap) (Droop, 1974). Ketika terjadi suatu pengurangan sumber nitrogen seperti amonia, mikroalga dikatakan tumbuh secara heterotropik.

Kajian mengenai alga heterotropik luas dan mencakup perwakilan organisme dari semua grup alga (Droop 1974; Neilson dan Lewin 1974 in Burrell et al., 1984). Salah satu teknik untuk meningkatkan kepadatan dan kandungan lipid mikroalga adalah kultivasi heterotropik. Pada produksi biodiesel, penambahan sumber karbon organik (glukosa) dari hidrolisat jagung ke dalam media dan penurunan sumber nitrogen inorganik pada medium menyebabkan pertumbuhan heterotropik mikroalga Chlorella menghasilkan kandungan minyak crude sebesar $55,2 \%$ atau 4 kali lebih besar dari kultivasi fotoautotrofik (Wu et al., 2006).

Karakteristik biodiesel yang dihasilkan dari kultivasi heterotropik pada fermentor memiliki heating value tinggi sebesar $41 \mathrm{MJ} / \mathrm{kg}$, densitas $0,864 \mathrm{~kg} / \mathrm{L}$ dan viskositas $5,2 \times 10 \mathrm{P}^{-4 \mathrm{P}} \mathrm{Pa}$ s(pada 
$\left.40^{\circ} \mathrm{C}\right)$. Pendekatan melalui fermentasi dengan kepadatan tinggi dari spesies Chlorella dan proses transesterifikasi enzim telah dilakukan dan terbukti dapat menjadi alternatif menjanjikan untuk produksi biodiesel (Wu et al, 2007).

Penelitian ini bertujuan untuk mengkaji pengaruh penggunaan hidrolisat singkong sebagai pengganti bahan dasar nutrien terhadap pertumbuhan mikroalga dengan cara menghitung pertumbuhan sel mikroalga yang dikultivasi pada skala laboratorium.

\section{MATERI DAN METODE}

Spesies mikroalga yang digunakan yaitu Nannochloropsis sp. dikultivasi pada skala laboratorium pada erlenmeyer $100 \mathrm{ml}$ yang ditempatkan di ruangan terbuka dengan ditutupi plastik hitam agar tidak ada pengaruh cahaya kemudian diberikan 3 perlakuan komposisi media kultivasi yang berbeda. Kultivasi dilakukan selama tujuh hari. Standarisasi kepadatan mikroalga tidak dapat diseragamkan antar perlakuan sehingga pada penelitian ini standarisasi yang dilakukan adalah volume kultivasi.

\section{Prosedur Penelitian}

\section{Pengaruh Perlakuan Penggunaan Hidrolisat}

Pati singkong dapat diubah menjadi senyawa glukosa melalui proses hidrolisis sempurna yang terdiri dari dua tahap, yaitu :

1. Proses Likuifikasi

Proses ini disebut juga liquefaction atau cooking, bertujuan untuk mengubah pati menjadi molekul yang memiliki bobot molekul yang lebih kecil dari pati.

2. Proses Sakarifikasi

Proses sakarifikasi bertujuan untuk memecah dekstrin menjadi molekul yang lebih kecil, yaitu glukosa.

\section{Analisis Data}

Kepadatan mikroalga dihitung dengan rumus berikut (Isnansetyo, A. dan Kurniastuty. 1995) :

$$
\mathrm{N}=\mathrm{n} \times \frac{1}{\mathrm{~V}_{\mathrm{cg}}} \times \frac{\mathrm{A}_{\mathrm{cg}}}{\mathrm{A}_{\mathrm{a}}} \times \frac{1000 \mathrm{ml}}{\mathrm{V}_{\mathrm{c}}}
$$

Dimana: $\mathrm{N}=$ kepadatan mikroalga (ind $/ \mathrm{ml}$ )

$\mathrm{n}=$ jumlah mikroalga yang teramati

$\mathrm{V}_{\mathrm{cg}}=$ volume Cover glass (ml)

$A_{c g}=$ luas cover glass $\left(\mathrm{mm}^{2}\right)$

$A_{a}=$ luas lapang pandang $\left(\mathrm{mm}^{2}\right)$

$\mathrm{V}_{\mathrm{c}}=$ volume kultur $(\mathrm{I})$

Laju pertumbuhan spesifik mikroalga $(\mathrm{k})$ dihitung dengan rumus Hirata et al. (1981) :

$$
\mathrm{k}=\frac{\log \frac{N_{t}}{N_{0}}}{T_{t}-T_{0}} \quad \times 3,22
$$

Dimana:

$\mathrm{NB}_{\mathrm{tB}} \quad=$ Kepadatan mikroalga pada waktu $\mathrm{t}$

$\mathrm{NB}_{\mathrm{OB}}=$ Kepadatan mikroalga pada waktu o

$3,22=$ Konstanta

$\mathrm{T}_{0} \quad=$ Waktu awal

$\mathrm{T}_{\mathrm{t}} \quad=$ Waktu pengamatan

Pengaruh perbedaan komposisi penggunaan hidrolisat singkong terhadap pertumbuhan mikroalga diuji dengan analisis varian (Anova) menggunakan software microsoft Excel 2003.

\section{HASIL}

Kultivasi dilakukan secara heterotropik (tanpa cahaya) dan tanpa aerasi. Pengamatan dilakukan selama tujuh hari. Kultivasi dilakukan dengan 3 perlakuan yang berbeda menurut komposisi media yang digunakan. Hidrolisat yang digunakan berasal dari singkong dengan hasil perhitungan kadar glukosa sebesar $24,64 \%$. Komposisi media yang digunakan pada ke-3 perlakuan kultivasi, yaitu :

a. $25 \mathrm{ml}$ bibit mikroalga, $75 \mathrm{ml}$ air laut, tanpa hidrolisat $(A)$

b. $25 \mathrm{ml}$ bibit mikroalga, $25 \mathrm{ml}$ hidrolisat, $50 \mathrm{ml}$ air laut (B)

C. $25 \mathrm{ml}$ bibit mikroalga, $50 \mathrm{ml}$ hidrolisat, $25 \mathrm{ml}$ air laut $(C)$

Pada Tabel 1 disajikan data kepadatan mikroalga Nannochloropsis sp. yang dikultivasi pada erlenmeyer $100 \mathrm{ml}$. Kepadatan dihitung mulai hari ke-1 dengan asumsi kepadatan awal adalah sama.

Tabel 1. Kepadatan Nannochloropsis sp. dengan 3

\begin{tabular}{|c|c|c|c|}
\hline \multirow{2}{*}{$\begin{array}{c}\text { Hari } \\
\text { Pengamatan }\end{array}$} & \multicolumn{3}{|c|}{ Kepadatan (ind/ml) } \\
\hline & (A) & (B) & (C) \\
\hline 1 & $\begin{array}{c}63.33 \\
7\end{array}$ & 68.145 & 80.686 \\
\hline 2 & $\begin{array}{c}74.41 \\
5 \\
\end{array}$ & 67.726 & 84.031 \\
\hline 3 & $\begin{array}{c}48.91 \\
4\end{array}$ & 54.975 & 97.827 \\
\hline 4 & $\begin{array}{c}67.51 \\
7\end{array}$ & $\begin{array}{c}115.80 \\
4\end{array}$ & 172.661 \\
\hline 5 & $\begin{array}{c}24.24 \\
8\end{array}$ & 80.268 & 136.916 \\
\hline 6 & $\begin{array}{c}63.12 \\
8 \\
\end{array}$ & 96.991 & 104.516 \\
\hline 7 & $\begin{array}{c}46.19 \\
6\end{array}$ & 82.777 & 81.732 \\
\hline
\end{tabular}
perlakuan berbeda 
Dari tabel di atas dapat dilihat bahwa kepadatan kultivasi untuk perlakuan $\mathrm{A}$ mencapai nilai tertinggi pada hari ke-2 yaitu $74.415 \mathrm{ind} / \mathrm{ml}$ sementara untuk perlakuan $\mathrm{B}$ dan $\mathrm{C}$ adalah pada hari ke 4 yaitu $115.804 \mathrm{ind} / \mathrm{ml}$ dan $172.661 \mathrm{ind} / \mathrm{ml}$. Kepadatan kultivasi terrendah untuk perlakuan $A$ yaitu pada hari ke-5 sebesar 24.248 ind $/ \mathrm{ml}$ sementara untuk perlakuan $B$ dan $C$ terrendah pada hari ke-3 dan hari ke-1, masing-masing sebesar $54.975 \mathrm{ind} / \mathrm{ml}$ dan $80.686 \mathrm{ind} / \mathrm{ml}$.
Dari ke-3 perlakuan dapat dilihat bahwa kepadatan kultivasi tertinggi terdapat pada perlakuan $\mathrm{C}$ (penambahan hidolisat $50 \mathrm{ml}$ ) di hari ke-4 sebesar $172.661 \mathrm{ind} / \mathrm{ml}$ sementara perlakuan $B$ dan perlakuan A memiliki kepadatan terrendah di hari ke-6, masing-masing sebesar $54.975 \mathrm{ind} / \mathrm{ml}$ dan $24.248 \mathrm{ind} / \mathrm{ml}$. Grafik pertumbuhan Nannochloropsis sp. selama penelitian disajikan pada Gambar 1.

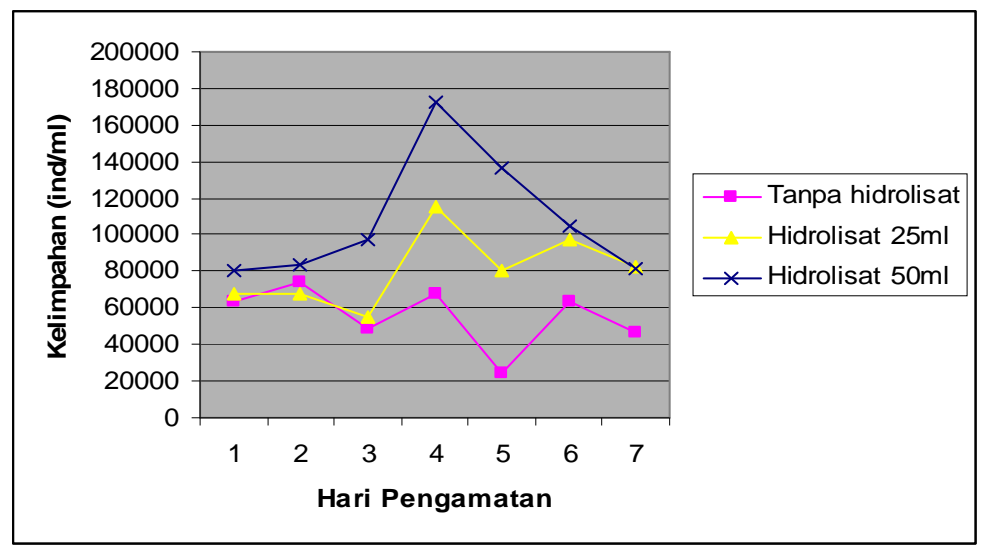

Gambar 1. Grafik pertumbuhan Nannochloropsis sp. selama penelitian

Dari grafik di atas terlihat bahwa perumbuhan mikroalga setiap hari antara satu perlakuan dengan perlakuan yang lain berbeda. Kepadatan mikroalga mengalami peningkatan hingga mencapai puncaknya pada hari ke-4 untuk perlakuan $\mathrm{B}$ dan $\mathrm{C}$ atau dengan penggunaan media hidrolisat singkong. Penggunaan hidrolisat singkong diketahui dapat meningkatkan kepadatan mikroalga pada kultivasi heterotropik (tanpa cahaya). Semakin tinggi komposisi penggunaan hidrolisat singkong, maka semakin tinggi pula kepadatan mikroalga hasil kultivasi. Puncak pertumbuhan mikroalga tertinggi dari ke-3 perlakuan dicapai pada perlakuan $\mathrm{C}$ (penambahan hidrolisat $50 \mathrm{ml}$ ) pada hari ke-4 sebesar 172.661 ind $/ \mathrm{ml}$. Secara keseluruhan perlakuan terbaik adalah perlakuan $\mathrm{C}(25 \mathrm{ml}$ bibit mikroalga, $50 \mathrm{ml}$ hidrolisat, $25 \mathrm{ml}$ air laut) pada hari ke-4.

Tabel 2. Laju pertumbuhan spesifik Nannochloropsis sp. dengan 3 perlakuan berbeda

\begin{tabular}{|c|c|c|c|c|c|c|}
\hline \multirow[t]{2}{*}{ Hari ke- } & \multicolumn{2}{|c|}{ (A) } & \multicolumn{2}{|c|}{ (B) } & \multicolumn{2}{|c|}{ (C) } \\
\hline & $\mu$ & $\mathrm{K}$ & $\mu$ & $\mathbf{K}$ & $\mu$ & $\mathbf{k}$ \\
\hline 1 & 63337 & - & 68145 & - & 80686 & - \\
\hline 2 & 74415 & 0,225 & 67726 & $-0,009$ & 84031 & 0,057 \\
\hline 3 & 48914 & $-0,587$ & 54975 & $-0,292$ & 97827 & 0,213 \\
\hline 4 & 67517 & 0,451 & 115804 & 1,042 & 172661 & 0,794 \\
\hline 5 & 24248 & $-1,432$ & 80268 & $-0,513$ & 136916 & $-0,324$ \\
\hline 6 & 63128 & 1,338 & 96991 & 0,265 & 104516 & $-0,378$ \\
\hline 7 & 46196 & $-0,437$ & 82777 & $-0,222$ & 81732 & $-0,344$ \\
\hline Rata-rata & 55394 & & 80955 & & 108338 & \\
\hline
\end{tabular}

Hasil pengamatan menunjukkan kepadatan akhir kultivasi yang tertinggi Nannochloropsis sp. adalah pada perlakuan penggunaan hidrolisat $25 \mathrm{ml}$ (B) yaitu sebesar $82.777 \mathrm{ind} / \mathrm{ml}$. Pola pertumbuhan mikroalga pada masing-masing perlakuan tidak selalu meningkat dari hari-ke hari. Kepadatan tertinggi masingmasing perlakuan diperoleh pada hari ke-2 pengamatan untuk perlakuan A dan pada hari ke-4 untuk perlakuan B dan C. Rata-rata kepadatan mikroalga tertinggi adalah pada perlakuan penggunaan hidrolisat singkong $50 \mathrm{ml}$ (C) sebesar $108.338 \mathrm{ind} / \mathrm{ml}$, tetapi laju pertumbuhan tertinggi adalah pada perlakuan tanpa hidrolisat singkong hari ke-6 yaitu 1,338/hari.

Berdasarkan hasil analisis statistik diketahui bahwa perlakuan penggunaan hidrolisat pada kultivasi mikroalga Nannochloropsis sp. secara heterotropik terhadap kepadatan mikroalga memberikan hasil yang berbeda nyata. Hal ini berarti penambahan hidrolisat singkong pada media kultivasi mikroalga secara heterotropik 
mempengaruhi kepadatan mikroalga (ind $/ \mathrm{ml}$ ). Namun, hasil analisis statistik tidak memberikan hasil yang berbeda nyata pada perlakuan penggunaan hidrolisat singkong terhadap laju pertumbuhan spesifik mikroalga (/hari).

\section{PEMBAHASAN}

Kepadatan Nannochloropsis sp. pada perlakuan $\mathrm{A}, \mathrm{B}$ dan $\mathrm{C}$ meningkat dan mencapai puncaknya pada hari ke-4. Hal ini disebabkan sumber karbon anorganik (glukosa) dan nutrien alami pada air laut tidak mencukupi untuk pertumbuhan Nannochloropsis sp. di hari ke-5 hingga hari ke-7 kultivasi. Kepadatan kultivasi tertinggi terdapat pada perlakuan $\mathrm{C}$ (penambahan hidolisat $50 \mathrm{ml}$ ) di hari ke-4 sebesar 172.661 ind $/ \mathrm{ml}$. Hal ini disebabkan komposisi hidrolisat singkong lebih tinggi dibandingkan dengan 2 perlakuan yang lain. Hidrolisat singkong dengan kandungan glukosa merupakan sumber karbon dan energi paling umum dalam memelihara pertumbuhan heterotropik (Wu et al, 2007).

Beberapa studi tentang kultivasi heterotropik mikroalga antara lain (Burrell et al., 1984) memperlihatkan biomassa akhir dari Chlorella vulgaris yang dikultivasi secara heterotropik pada media bristol adalah 26 dan 58 kali lebih tinggi dibandingkan hasil yang diperoleh dari sel yang tumbuh dengan cahaya secara autotrof. Dalam kajian bioenergi, Kultivasi heterotropik tidak hanya dapat digunakan untuk meningkatkan efisiensi dan mengurangi biaya produksi biomassa, tetapi juga dapat memberikan produksi efisien dari beberapa metabolit untuk produksi minyak nabati $(57,9 \%)$ yang diproduksi dari sel heterotropik atau 3,4 kali lebih tinggi dari sel autotropik (Miao, X dan Wu, Q, 2004).

Berdasarkan penelitian Wu et al, 2007, kurva pertumbuhan kultivasi Chlorella meningkat seiring dengan dengan penambahan konsentrasi glukosa dari hidrolisat jagung melalui proses fermentasi. Semakin tinggi konsentrasi glukosa yang digunakan, semakin tinggi pula biomassa mikroalga yang dihasilkan. Pendekatan melalui fermentasi dengan kepadatan tinggi dari kultivasi spesies Chlorella dan proses transesterifikasi enzim telah dilakukan dan terbukti dapat menjadi alternatif menjanjikan untuk produksi biodiesel.

Penggunaan hidrolisat berbahan baku singkong dapat menjadi alternatif kebutuhan glukosa khususnya bagi kultivasi mikroalga secara heterotropik. Disamping memberikan hasil kultivasi dengan kepadatan yang tinggi, metode ini juga dapat dikembangkan sebagai solusi kultivasi mikroalga baik sebagai bahan baku pakan perikanan maupun biodiesel pada kondisi tertentu seperti lokasi kultivasi dengan intensitas matahari rendah atau curah hujan tinggi. Kepadatan mikroalga hasil kultivasi yang tinggi tidak selalu diiringi oleh laju pertumbuhan spesifik yang tinggi pada kultivasi Nannochloropsis sp. yang diperoleh pada penelitian ini.

\section{KESIMPULAN}

Kesimpulan penelitian ini antara lain :

1. Perlakuan $C$ (penambahan hidrolisat $50 \mathrm{ml}$ ) dari ke-3 perlakuan memberikan hasil kultivasi terbaik dengan kepadatan kultivasi Nannochloropsis sp. tertinggi pada hari ke-4 sebesar $172.661 \mathrm{ind} / \mathrm{ml}$.

2. Hasil analisis statistik menunjukkan bahwa perlakuan penggunaan hidrolisat singkong pada kultivasi heterotropik mempengaruhi kepadatan mikroalga (ind $/ \mathrm{ml}$ ), tetapi tidak mempengaruhi laju pertumbuhan spesifik mikroalga (/hari).

\section{DAFTAR PUSTAKA}

Chisti, Y. 2007. Biodiesel from microalgae. Research review paper. Biotechnology Advances. Elsevier. 25: 297-306.

Burrell, R.E; Inniss, W.E; dan Mayficld, C.I. 1984. Development of an optimal heterotrophic growth medium for Chlorella vuigaris. Appl Microbiol Biotechnol (1984) 20:281-283.

Droop, M. R. 1974. Heterotrophy of carbon, p. 530559. In W. D. P. Stewart (ed.), Botanical monographs, vol. 10, Algal physiology and biochemistry. Blackwell Scientific Publications, Oxford.

Hirata, H., I, Andarias dan S,Yamasaki. 1981. Effect of Salinity Temperature on the Growth of The Marine Phytoplankton Chlorella saccharophila. Mem. Fac. Fish. Kaghosima Univ. $30: 257-262$.

Isnansetyo, A. dan Kurniastuty. 1995. Teknik Kultur Phitoplankton dan Zooplankton Pakan Alami untuk Pembenihan Organisme Laut. Penerbit Kanisius. Yogyakarta.

Lavens, P. dan P. Sorgeloos (eds). 1996. Manual on the Production and Use of Live Food for Aquaculture. FAO Fisheries Technical Paper. No. 361. Food and Agriculture Organization of the United Nations. Rome.

Miao, X dan Wu, Q. 2004. High yield bio-oil production from fast pyrolysis by metabolic controlling of Chlorella protothecoides. Journal of Biotechnology 110 (2004) 85-93.

Wu, Q.; Miao, X.,; dan Xu, Han. 2006. High quality biodiesel production from a microalga Chlorella protothecoides by heterotrophic growth in fermenters. Elsevier B. V.

Wu, Q.; dan Xiaoling M. 2007. Biofuels production from Microalgae after heterotrophic growth. Department of Biological Sciences and Biotechnology. Tsinghua University. Beijing. P.R.China. 
Wu, Q.; Xiong, W.; Li, X; dan Xiang, J. 2007.

High density fermentation of microalga Chlorella protothecoides in bioreactor for microbio-diesel production. Appl Microbiol Biotechnol 78: 29-36. 